\title{
Molecular fragment dynamics study on the water-air interface behavior of non-ionic polyoxyethylene alkyl ether surfactants
}

\author{
Andreas Truszkowski ${ }^{*}$, Annamaria Fiethen ${ }^{2}$, Hubert Kuhn², Thomas Wiebringhaus ${ }^{3}$, Achim Zielesny $^{3}$, \\ Matthias Epple ${ }^{1}$
}

From 9th German Conference on Chemoinformatics

Fulda, Germany. 10-12 November 2013

Molecular Fragment Dynamics (MFD) is a mesoscopic simulation technique based on Dissipative Particle Dynamics (DPD). Whereas DPD beads in general may not necessarily be identified with chemical compounds at all the MFD variant uses specific molecules or molecular fragments as its basic coarse-grained interacting entities (rather than the fine-grained atom types of Molecular Mechanics). MFD can be used to study formulations of drugs and active agents in oil, water and emulsions.
MFD simulations of the nonionic polyoxyethylene alkyl ether surfactants $\mathrm{C}_{6} \mathrm{E}_{6}, \mathrm{C}_{10} \mathrm{E}_{6}, \mathrm{C}_{12} \mathrm{E}_{6}$ and $\mathrm{C}_{16} \mathrm{E}_{6}$ at the water-air interface are performed to study their nanoscale structures and surface properties. The simulations of the self-aggregation of the polyoxyethylene alkyl ether surfactants lead to equilibrium nanoscale structures and computationally determined surface tensions which are in agreement with experimental data for different surfactant concentrations [1].

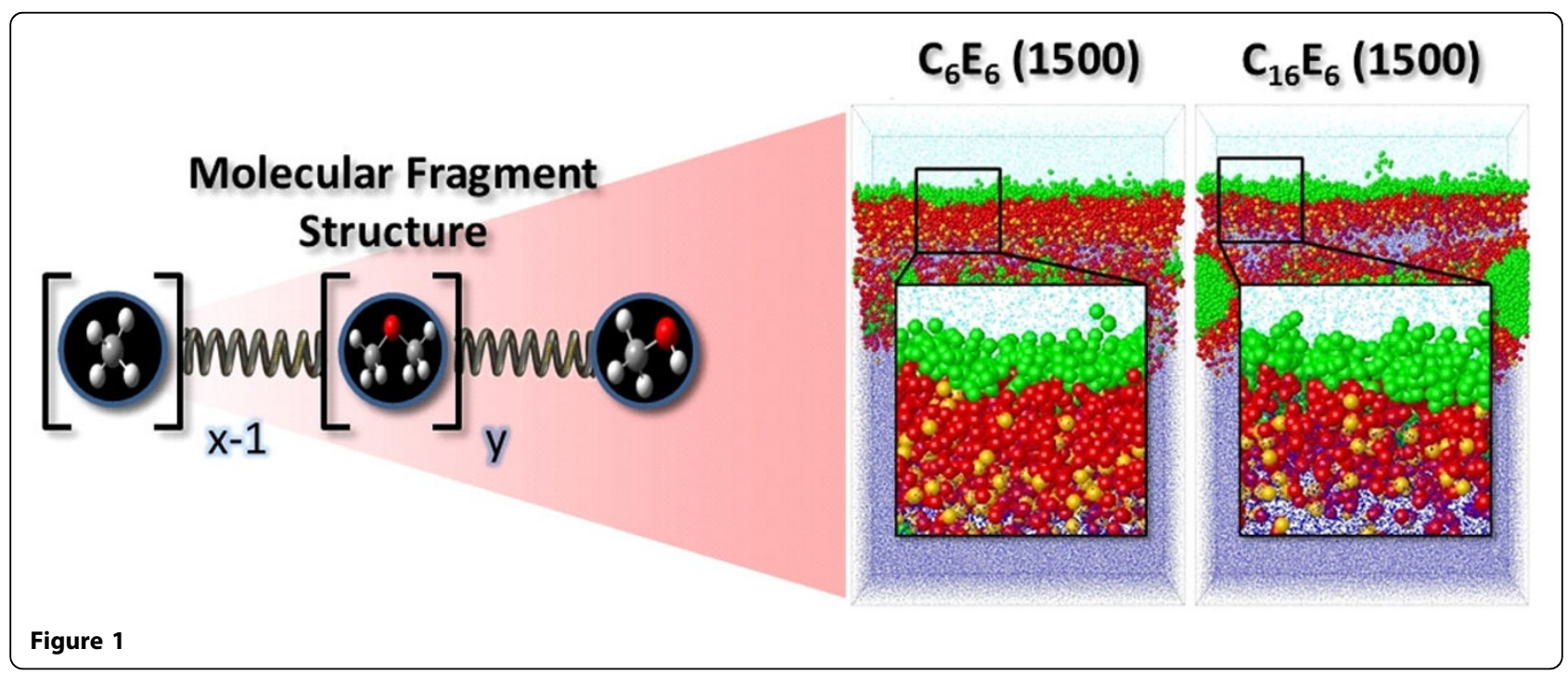

IInorganic Chemistry and Center for Nanointegration, University of Duisburg-

Essen, Essen, 45141, Germany

Full list of author information is available at the end of the article 


\section{Authors' details}

'Inorganic Chemistry and Center for Nanointegration, University of DuisburgEssen, Essen, 45141, Germany. ${ }^{2}$ CAM-D Technologies, Essen, 45117, Germany. ${ }^{3}$ Institute for Bioinformatics and Chemoinformatics, Westphalian University of Applied Sciences, Recklinghausen, 45665, Germany.

Published: 11 March 2014

\section{Reference}

1. Truszkowski A, Epple M, Fiethen A, Zielesny A, Hubert K: Molecular fragment dynamics study on the water-air interface behavior of nonionic polyoxyethylene alkyl ether surfactants. Journal of Colloid and Interface Science, accepted.

doi:10.1186/1758-2946-6-S1-P9

Cite this article as: Truszkowski et al:: Molecular fragment dynamics study on the water-air interface behavior of non-ionic polyoxyethylene alkyl ether surfactants. Journal of Cheminformatics 2014 6(Suppl 1):P9.

\section{Publish with ChemistryCentral and every scientist can read your work free of charge}

"Open access provides opportunities to our colleagues in other parts of the globe, by allowing anyone to view the content free of charge."

W. Jeffery Hurst, The Hershey Company.

- available free of charge to the entire scientific community

- peer reviewed and published immediately upon acceptance

- cited in PubMed and archived on PubMed Central

- yours - you keep the copyright

Submit your manuscript here:

http://www.chemistrycentral.com/manuscript/<smiles>c1ccccc1</smiles>
Chemistry Central 